速報

\title{
酸素プラズマによる立体形状炭素材料の 表面改質と改質領域*
}

\author{
泉順** ·加藤 正明**.大手 丈夫** \\ 大谷 杉郎***. 小島 昭**. 根岸 恒雄 ${ }^{* *}$
}

（受理1994年12月 2 日，掲載決定1995年 6 月 3 日）

\begin{abstract}
Surface Modification and its Modified Area of the Cubic-shape
Carbon Material by the Oxygen Plasma

Yori IZUMI**, Masaaki KATOH ${ }^{* *}$, Takeo OHTE**, Sugio OHTANI***, Akira KOJIMA** and Tuneo NEGISHI ${ }^{* *}$

** (Gunma College of Technology, Toriba-cho, Maebashi-shi, Gunma 371)

***(Tokai University, Nishino, Namazu-shi, Shizuoka 410-03)
\end{abstract}

(Received December 2, 1994, Accepted June 3, 1995)

\section{1. はじめに}

炭素材料のもつ機能性をより向上させるために，プラ ズマを用いて表面を改質する方法がある ${ }^{1-3)}$. 最近, 生 産性向上の観点から，一度に大量の炭素材料を，あるい は様々な形状の炭素材料をプラズマで改質処理すること が必要となっだ)。この場合には, 改質しようとする材 料の全表面が, プラズマの作用によって均一に処理され るか否かが重要である. しかし，材料同士が近接して， あるいは接触して置かれた場合, プラズマによる表面改 質効果は，材料の全表面に均一に及んでいるかどらかは 明確ではない、例えば，筆者らのこれまでの実験結果に よれば，炭素材料を電極上でプラズマ処理した場合，プ ラズマにさらされている材料面は改質されていたが，電 極面と接している材料面は，ほとんど改質作用を受けて いなかった ${ }^{5)}$ 。プラズマによる表面改質は, 半導体材料 など平面的な高付加価值材料への少量処理が中心であっ たため6,7)，プラズマ作用の及ぼす改質領域に関しては,

* 平成 6 年 10 月 28 日第 35 回真空に関する連合講演会で講演（講演番号 28Ba-5)

** 群馬工業高等専門学校 (厂 371 群馬県前橋市鳥羽町580番地)

*** 東海大学（干410-03 静岡県沼津市西野317）
ほとんど検討が加えられていなかった.

本研究は, 立体形状を持つ炭素材料の表面をプラズマ で改質する場合の, 改質される領域について検討するこ とを目的とした，そのためには，最も単純な形態をもつ 実験モデル（箱状直方体の一面を開口したもの）を用い, その直方体の内側に向かってプラズマ処理を行い, その 際の放電条件（特に入力電力）が, 直方体内側面の改質 度合に対してどのような影響を与えるのか, また直方体 の形状 (深さ, 開口部の広さ) などによって, 改質状況 はどら影響されるのかを検討した。

\section{2. 実験方法}

\section{1 炭素材料}

炭素材料は, ガラス状カーボン板 (GC 板, 昭和電工 $\mathrm{KK}$ 製, SG-2, 縦 $2.5 \mathrm{~cm}$, 横 $5.0 \mathrm{~cm}$, 厚さ $0.06 \mathrm{~cm}$ ) を 用いた. GC 板はアセトンおよび水で洗浄後, 乾燥して から使用した.

\section{2 改質領域検討用試料の作成}

プラズマ処理による改質領域を検討するために, GC 板を使用した Fig. 1 に示す直方体を作った. Fig. 1 の (a)は, 試料の概略図を, Fig. 1 の(b)は, 直方体の上面 図及び側面図である。これらの図に示した直方体は，六 


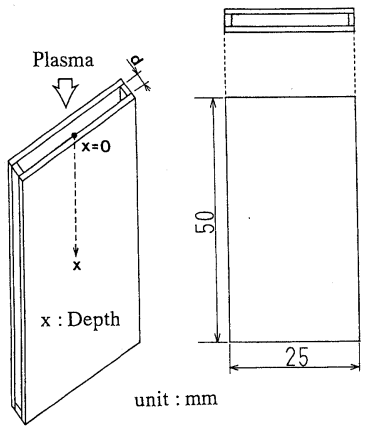

(a) (b)
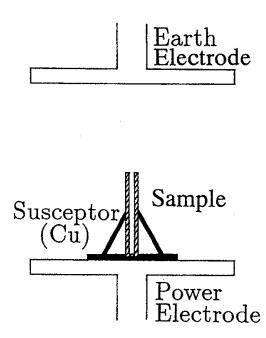

(c)
Fig. 1 Sample used in the experiment.

つの面のらち最小の一面は GC 板を設けていない空間 のままである，直方体は，側面になる大さい二片（50 $\mathrm{mm} \times 25 \mathrm{~mm})$ と，同じく側面を形成する二片（50 $\mathrm{mm} \times$ 所定幅）と底面になる一片とから構成されてい た。この場合の所定幅 (Fig. 1(a)中の $d$ ) は, $0.6 \mathrm{~mm}$, $1.2 \mathrm{~mm}, 1.8 \mathrm{~mm}$ あるいは4.8 $\mathrm{mm}$ であった。この幅はま た，大きい二片間の距離でもあり，以後材料間距離と呼 ぶ.この直方体試料は, 薄手のテフロンテープを巻いて 固定して作った．開口部の形はいずれの場合も長方形で あった。

このような直方体試料を, Fig. 1 の (c) と示すように, その開口部が上部電極（アース電極）に向かい，両電極 （パワー電極拉よびアース電極）と平行になるように設 置し，さらに，倒れないように銅製の治具を用いて固定 した．直方体は，電極と電気的に接続しておいた。 そし て直方体内面の上部箱の開口部からの距離は, $x$ とし た.したがって, 開口部での $x$ は $0.0 \mathrm{~cm}$, 底部での $x$ は $5.0 \mathrm{~cm}$ である.

\section{3 プラズマ処理}

直方体試料のプラズマ処理は, 平行平板電極型のプラ ズマ処理装置（自作装置）を用いた。直方体試料は放電 容器 (アルミニウム製, 円筒型, 直径 $44 \mathrm{~cm}$, 高さ21 $\mathrm{cm}$ ) 内の下部電極（アルミニウム製，パワー電極，直 径 $21 \mathrm{~cm}$ ) 上に置き, 真空ポンプで放電容器内を予備排 気した後, 酸素ガスを50 sccm 流し, 所定圧力（10 Pa〜 $60 \mathrm{~Pa}$ ) に調整した. RF グロー放電プラズマは, 上部電 極（アルミニウム製, アース電極, 直径 $22.5 \mathrm{~cm}$ ) で発 生させ, 2 分間プラズマ処理を行った。

\section{4 測定および観察}

プラズマ処理後の直方体は, 各面をばらばらにした 後, 側面を構成していた大きい方の GC 板について, 次の測定および観察を行った。水に対する接触角値は,

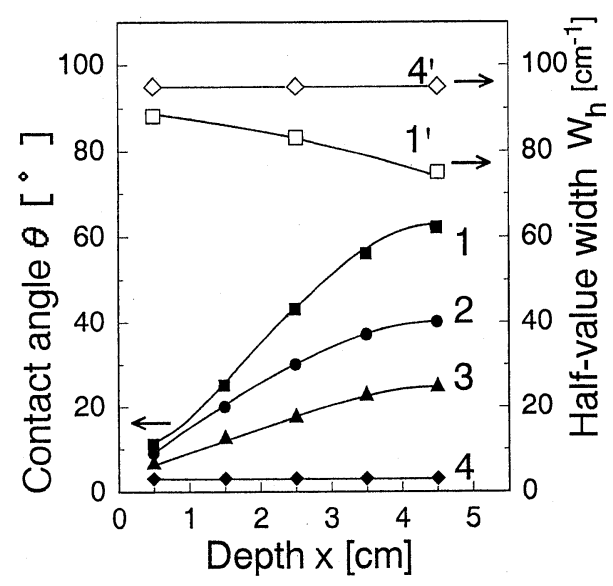

Fig. 2 Typical data of the contact angle $\theta$ and halfvalue width $W_{h}$ against the depth $x$ in case of varying the distance $d$ between the GC plates.

(input power: $120 \mathrm{~W}$, pressure: $20 \mathrm{~Pa}$, gas flow rate: $50 \mathrm{sccm}$, gap: $8 \mathrm{~cm}$, treatment time: 2 minute)

Contact angle of water to GC surface:

1: $0.6 \mathrm{~mm}, 2: 1.2 \mathrm{~mm}, 3: 1.8 \mathrm{~mm}, 4: 4.8 \mathrm{~mm}$ Half-value width of Raman band at $1360 \mathrm{~cm}^{-1}$. $1^{\prime}: 0.6 \mathrm{~mm}, 4^{\prime}: 4.8 \mathrm{~cm}$

ゴニオメーター式接触角測定器（エルマ光学 KK 製, G-I）を用い，GC 板の中央部を測定した ${ }^{5)}$. GC 板の表 面状況は，走査型電子顕微鏡（SEM，日立製作所 $\mathrm{KK}$ 製，S-2050）で観察した。また，レーザーラマンスペ クトルは, レーザーラマン分光光度計（スペックス社 製，ラマログ1402，アルゴンイオンレーザー；5145 および日本分光工業 $\mathrm{KK}$ 製, NR-1100，アルゴンイオ ンレーザー；5145 ̊）で測定した。ささらに，GC 板表面 上に存在する元素，およびその結合状態などは，X線 光電子分析装置 (ESCA, 島津製作所 $\mathrm{KK}$ 製, ESCA850）により求め, $\mathrm{O} / \mathrm{C}$ 值を算定した.

\section{3. 実験結果と考察}

3.1 直方体内面の接触角値とラマンスペクトル

(1) 材料間距離を変化させた場合

圧力を $20 \mathrm{~Pa}$ ，入力電力を $120 \mathrm{~W}$ ，で 2 分間，直方体 試料を酸素プラズマで処理した．材料間距離 $(d)$ を, $0.6 \mathrm{~mm}$ から $4.8 \mathrm{~mm}$ まで変化させた場合の, 試料の開 口部からの所定深さ $(x)$ と接触角值 $(\theta)$ との関係を Fig. 2 に示す. $d$ が4.8 $\mathrm{mm}$ の場合（Fig. 2 の曲線 4) は, 開口部から底部付近にわたって接触角値は一様に 3 度程度であり, 未処理の值（90度）より著しく小さくな っていた．GC板は全面にわたって十分に改質されてい た.これに対し， $d$ が0.6 mm の場合（Fig. 2 の曲線 1)， 
開口部付近 $(x=0.5 \mathrm{~cm})$ での接触角值は 11 度であるが， 直方体の底部付近 $(x=4.5 \mathrm{~cm})$ では，62度まで増えて いた.このことから，プラズマの改質領域は底部付近に まで及んではいたが，改質度合いは低くなっていた。さ らに，二枚の GC 板を接触させた場合 $(d=0.0 \mathrm{~mm})$ の 接触角値は，ほぼ全面にわたって 90 度で，未処理の場合 と同じであり，プラズマによる改質効果はまったくなか った.

GC 表面のラマンスペクトルは，プラズマ処理の有無 にかかわらず, $1360 \mathrm{~cm}^{-1}$ と $1580 \mathrm{~cm}^{-1} に 2$ 本の強いピ

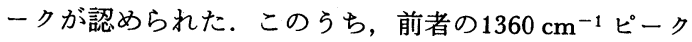
の半值幅は, 炭素材料表面構造の変形（破壊）された程 度を示す ${ }^{8-10)}$ ので, 材料間距離 $d$ を変化させた場合の分 布をFig. 2 上段に示す。この場合の縦軸の目盛りは， 右側に示した. $d$ が0.6 mmの場合 (Fig. 2 の曲線 $1^{\prime}$ ), 開口部付近 $(x=0.5 \mathrm{~cm})$ での半値幅は $88 \mathrm{~cm}^{-1}$, 中央部 付近 $(x=2.5 \mathrm{~cm})$ では $83 \mathrm{~cm}^{-1}$, 底部付近 $(x=4.5 \mathrm{~cm})$ では, $75 \mathrm{~cm}^{-1}$ であり, 直方体の内部へ行くほど小さく なり，未処理の場合の值 $\left(65 \mathrm{~cm}^{-1}\right)$ に近づいていた. そして，開口部を広く（d=4.8 mm） した場合（Fig. 2 の曲線 $\left.4^{\prime}\right)$ には, 半值幅は一様に $95 \mathrm{~cm}^{-1}$ であった。し たがって, 接触角値に示される炭素材料表面の改質度合 と, ラマンスペクトルに示される表面構造の乱れとの間 には，相関がやや見られた。

（2）入力電力を変化させた場合

材料間距離を $1.2 \mathrm{~mm}$ とし, プラズマ処理時の入力電 力を $20 \mathrm{~W}$ から $200 \mathrm{~W}$ まで変化させた場合の, 開口部か らの深さ $(x)$ とその地点における接触角值との関係を Fig. 3 に示す. 入力電力が $20 \mathrm{~W}$ の場合（Fig. 3 の曲線 1), 開口部付近 $(x=0.5 \mathrm{~cm})$ での接触角值は 38 度であ り, 未処理の値 (90度) よりかなり小さくなっていた. ところが, 底部付近 $(x=4.5 \mathrm{~cm})$ になると, 未処理の 場合と同じ接触角值 (90度)となっていた。 これに対し， 入力電力が $200 \mathrm{~W}$ (Fig. 3 の曲線 5) では，接触角值は ほぼ全面にわたって 3 度であった。

ラマンスペクトルにみられる $1360 \mathrm{~cm}^{-1}$ ピークの半値 幅は, $20 \mathrm{~W}$ 処理時 (Fig. 3 の曲線 1') の值よりも200 $\mathrm{W}$ 処理時 (Fig. 3 の曲線 5') の方が，いずれの地点で も高かった，接触角值は，いずれの地点でも等しいにも かかわらず, ラマンスペクトルの半值幅は直方体の底部 $(x=4.5 \mathrm{~cm})$ に近づくにしたがって小さくなり，表面構 造の変形が不均一であったことを示している.

\subsection{SEMによる表面観察}

材料間距離を $1.2 \mathrm{~mm}$ とし, プラズマ処理の入力電力

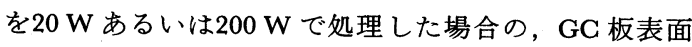
の開口部（Fig. 4のBとD）を底部（Fig. 4の C と E）

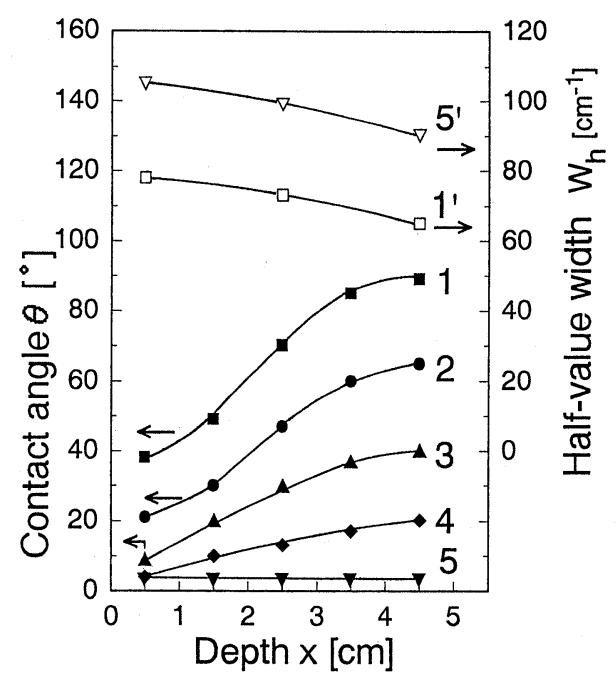

Fig. 3 Typical data of the contact angle $\theta$ and halfvalue width $W_{h}$ against the depth $x$ in case of varying the input power $P$.

(distance between the GG plates: $1.2 \mathrm{~mm}$, pressure: $20 \mathrm{~Pa}$, gas flow rate: $50 \mathrm{sccm}$, gap: $8 \mathrm{~cm}$, treatment time: 2 minute)

Contact angle of water to GC surface:

1: $20 \mathrm{~W}, 2: 50 \mathrm{~W}, 3: 120 \mathrm{~W}, 4: 160 \mathrm{~W}, 5: 200 \mathrm{~W}$

Half-value width of Raman band at $1360 \mathrm{~cm}^{-1}$ :

$1^{\prime}: 20 \mathrm{~W}, 5^{\prime}: 200 \mathrm{~W}$

の SEM 写真を Fig. 4 に示す．入力電力が $200 \mathrm{~W} て ゙$ 処理 した場合は，開口部付近（Fig. 4 中の B）では非常に激 しくェッチングされており，小さな粒子が多数生じてい た。 また，底部付近（Fig. 4 中の C）でも，エッチング は進行していたが，開口部より改質度合いは低かった。

Fig. 3 の曲線 5 に示したように，両部分での接触角值は ともに 3 度で, プラズマによって改質されていることを 示していたが，表面形状は不均一であった．次に，入力 電力を $20 \mathrm{~W}$ で処理した場合, 開口部付近ではェッチン グされていたが（Fig. 4の中のD)，底部付近では，ほ とんどェッチングはなされてなく（Fig.4中のE），末 処理の表面（Fig. 4 中のA）とほぼ同じであった. Fig. 3 の曲線 1 と合わせて考えると, 入力電力が $20 \mathrm{~W}$ の場 合には, プラズマによる改質は, 底部にまでは波及して いないといえる.

\subsection{ESCA による表面分析}

材料間距離を $1.2 \mathrm{~cm}$ でプラズマ処理した GC 表面の $\mathrm{O} / \mathrm{C}$ 值は, 入口付近 $(x=0.5 \mathrm{~cm})$ では 0.21 , 中央 $(x=2.5 \mathrm{~cm})$ では 0.14 , 底部付近で值は, $0.11 て ゙ あ り$, 直方体の底部に近づくほど， O/C 值は小さくなってい た.このことは, プラズマ処理により導入された含酸素 

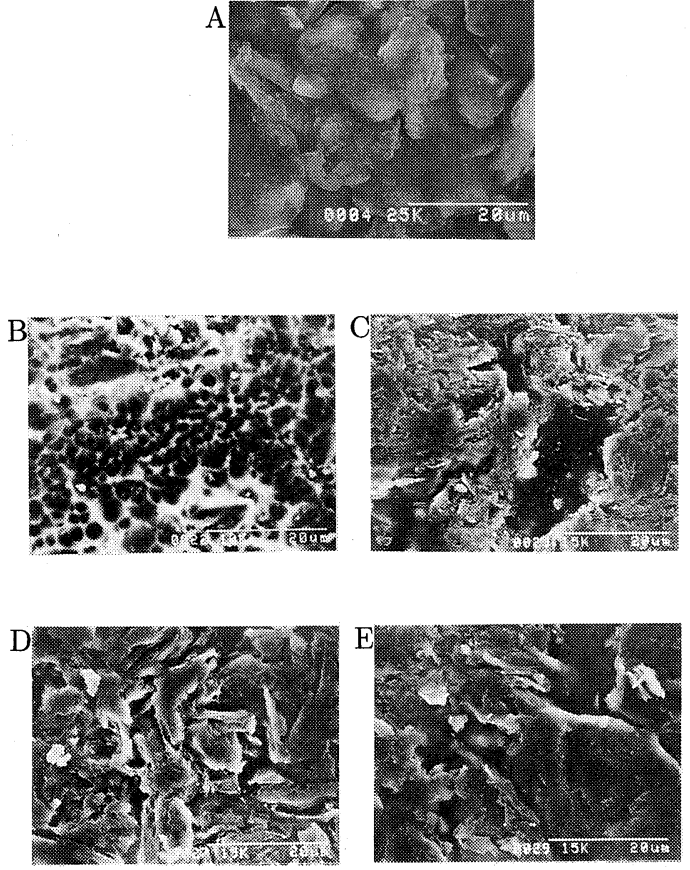

$20 \mu \mathrm{m}$

Fig. 4 SEM photographs of glassy carbon surfaces treated by $\mathrm{O}_{2}$ plasma at the places, $x=0.5 \mathrm{~cm}$ and $x=4.5 \mathrm{~cm}$ in case of varying the input power $P$. (distance between the GC plates: $1.2 \mathrm{~mm}$, pressure: $20 \mathrm{~Pa}$, gas flow rate: $50 \mathrm{sccm}$, gap: $8 \mathrm{~cm}$, treatment time: 2 minute)

A: untreated, B: $x=0.5 \mathrm{~cm}, P=200 \mathrm{~W}, \mathrm{C}: x=4.5$ $\mathrm{cm}, P=200 \mathrm{~W}, \mathrm{D}: x=0.5 \mathrm{~cm}, P 20 \mathrm{~W}, \mathrm{E}: x=4.5$ $\mathrm{cm}, P=20 \mathrm{~W}$.

基は減少していることを示している．言い換えれば，直 方体内部の改質の程度は少ないといえる.

以上の実験結果から，プラズマ処理による改質領域 は, 直方体内の材料間距離, プラズマ発生時の入力電力 によって左右された。
たとえば，材料間距離が $4.8 \mathrm{~cm}$ では，プラズマ処理 による改質領域は，開口部から $4.5 \mathrm{~cm}$ ほど離れた直方 体の底部まで及んでいた，そして，炭素材料表面の構造 の乱れの度合いや，エッチングの程度は，いずれの直方 体内面でも一定であった。これに対し，材料間距離が $1.2 \mathrm{~mm}$ の場合では, 深さ方向での表面改質状態は不均 一であった．さらに，材料間距離が $0.6 \mathrm{~mm}$ 程度と小さ い場合には，プラズマ処理による改質領域は，直方体の 底部にまで達していたが，改質の程度は十分ではなかっ た。

これらのことから, 直方体試料内での改質度合いは, (1)直方体内部での改質源の発生状態（すなわち, 放電の 有無），(2)改質源の直方体内部への侵入状態，(3)圧力に よるプラズマの密度，(4)平均自由行程などに左右される と考えられるが, 改質源のより詳細な検討が必要であ る.さらに, 改質領域に関しての詳細なメカニズムは, 放電時の圧力, 処理時間など他のプラズマパラメータを も検討することによって解明する予定である.

\section{[文献〕}

1）井原辰彦, 伊藤征司郎, 桑原利秀, 木卜光雄 : 日 本化学会誌 (1984), p. 1575.

2）加西英一, 岡崎幸子: 表面科学 6, (1985), p. 116 .

3) K. Esumi, M. Sugihara, T. Mori, K. Meguro and H. Honda : 炭素 1986 [No. 125], p. 57.

4）長田義仁編著: 低温プラズマ材料化学, 産業図書, (1994), p. 219.

5）大手丈夫, 大谷杉郎, 小島 昭, 加藤正明 : 真空 36, (1993), p. 8

6）菅野卓男：半導体プラズマプロセス技術，産業図 書, (1980), p. 211.

7) Brian N Chapman: Glow Discharge Processes, John Wiley \& Sons, Inc., New York, (1980)m p. 297.

8) M. Nakamizo, H. Honda and M. Inagaki: Carbon 16, (1978), p. 281.

9）中溝 実, 玉井桂子：炭素 1984 [No. 117], p. 94.

10）大手丈夫, 大谷杉郎, 小島 昭, 加藤正明 : 真空 36, (1993), p. 643. 